\title{
Has air quality improved in Ecuador during the COVID-19 pandemic? A parametric analysis
}

\author{
Manuel A. Zambrano-Monserrate ${ }^{1}$ (D) $\cdot$ María Alejandra Ruano $^{2}$ (D) \\ Received: 27 May 2020 / Accepted: 30 June 2020 / Published online: 6 July 2020 \\ (C) Springer Nature B.V. 2020
}

\begin{abstract}
Many governments around the world have enforced quarantine policies to control the spread of the new coronavirus (SARSCoV-2). These policies have had positive and negative effects on the environment. For example, the concentrations of certain harmful pollutants have decreased in some countries. In contrast, the concentrations of other pollutants have increased. This research analyzes the effect of quarantine policies on air quality in Quito, Ecuador. Using a parametric approach, it was found that $\mathrm{NO}_{2}$ and PM2.5 concentrations have decreased significantly since the establishment of lockdown measures. However, $\mathrm{O}_{3}$ concentrations have increased considerably in 2020.
\end{abstract}

Keywords Air quality $\cdot$ Pollution $\cdot \mathrm{NO}_{2} \cdot \mathrm{PM} 2.5 \cdot \mathrm{O}_{3} \cdot \mathrm{COVID}-19 \cdot$ Ecuador

\section{Introduction}

COVID-19 is an infectious disease caused by the new coronavirus SARS-CoV-2. It was first discovered in the city of Wuhan, China (WHO 2020). Since its appearance, COVID19 has affected most countries in the world, causing high mortality rates among its inhabitants.

Ecuador, a country located in South America (Fig. 1), has been one of the most affected countries by the pandemic. This nation has the highest number of COVID-19 infections and deaths per capita in South America, and it is second in all of Latin America, only behind Panama (Coronavirus Resource Center 2020). This outcome ocurred even though Ecuador was one of the first countries of the region to establish quarantine policies. $^{1}$

Quarantine policies have generated direct effects on the country's economic activities. During March and April 2020, many industries stopped their production and services. For example, all public transportation was paralyzed. Mobilization in

\footnotetext{
${ }^{1}$ Since March 17, 2020, the government of Ecuador decreed a state of emergency in the country. To date, some prohibitions are still in force.
}

Manuel A. Zambrano-Monserrate

manuelzambranom@uees.edu.ec

Universidad Espíritu Santo, Samborondón, Ecuador

2 Facultad de Ciencias Sociales y Humanísticas, Escuela Superior Politécnica del Litoral, ESPOL, Campus Gustavo Galindo Km 30.5 Vía Perimetral, P.O. Box 09-01-5863, Guayaquil, Ecuador private transportation was also restricted. During those months, car circulation was only allowed 1 day per week according to the license plate's final number at a specific time frame (from 05:00 to 14:00) (Ministerio de Gobierno 2020). In general, only activities related to health and food were allowed.

Lockdown measures could generate positive and negative externalities on the environment. For example, quarantine policies have caused nitrogen dioxide $\left(\mathrm{NO}_{2}\right)$ concentrations to decrease considerably in some countries such as China (Zhao et al. 2020; Wang and Su 2020; Isaifan 2020), Brazil (Nakada and Urban 2020), India (Mahato et al. 2020), Kazakhstan (Kerimray et al. 2020), the USA (Berman and Ebisu 2020), Spain, France, and Italy (Gautam 2020). $\mathrm{NO}_{2}$ is a component of nitrogen oxides that play an important role in tropospheric chemistry, including the formation of ozone $\left(\mathrm{O}_{3}\right)$, the production of aerosols, and the acid deposition (Cui et al. 2019). Exposing the population to high concentrations of $\mathrm{NO}_{2}$ could cause health problems (cardiovascular and respiratory) and increase mortality risks (Chen et al. 2012; Xing et al. 2016; Reddington et al. 2019).

On the other hand, lockdown policies have also caused concentrations of fine particles (PM2.5) to decrease in some countries such as China ( $\mathrm{Li}$ et al. 2020), India (Sharma et al. 2020; Mahato et al. 2020), Kazakhstan (Kerimray et al. 2020), and the USA (Berman and Ebisu 2020). The PM2.5 are microscopic particles in the air that have a diameter equal or lower than $2.5 \mu \mathrm{m}$ and are considered air pollutants (Seinfeld and Pandis 2016; Zambrano-Monserrate et al. 2020). Prolonged exposure to these particles could cause cancer (Khaniabadi et al. 2017; Latza et al. 2009). 

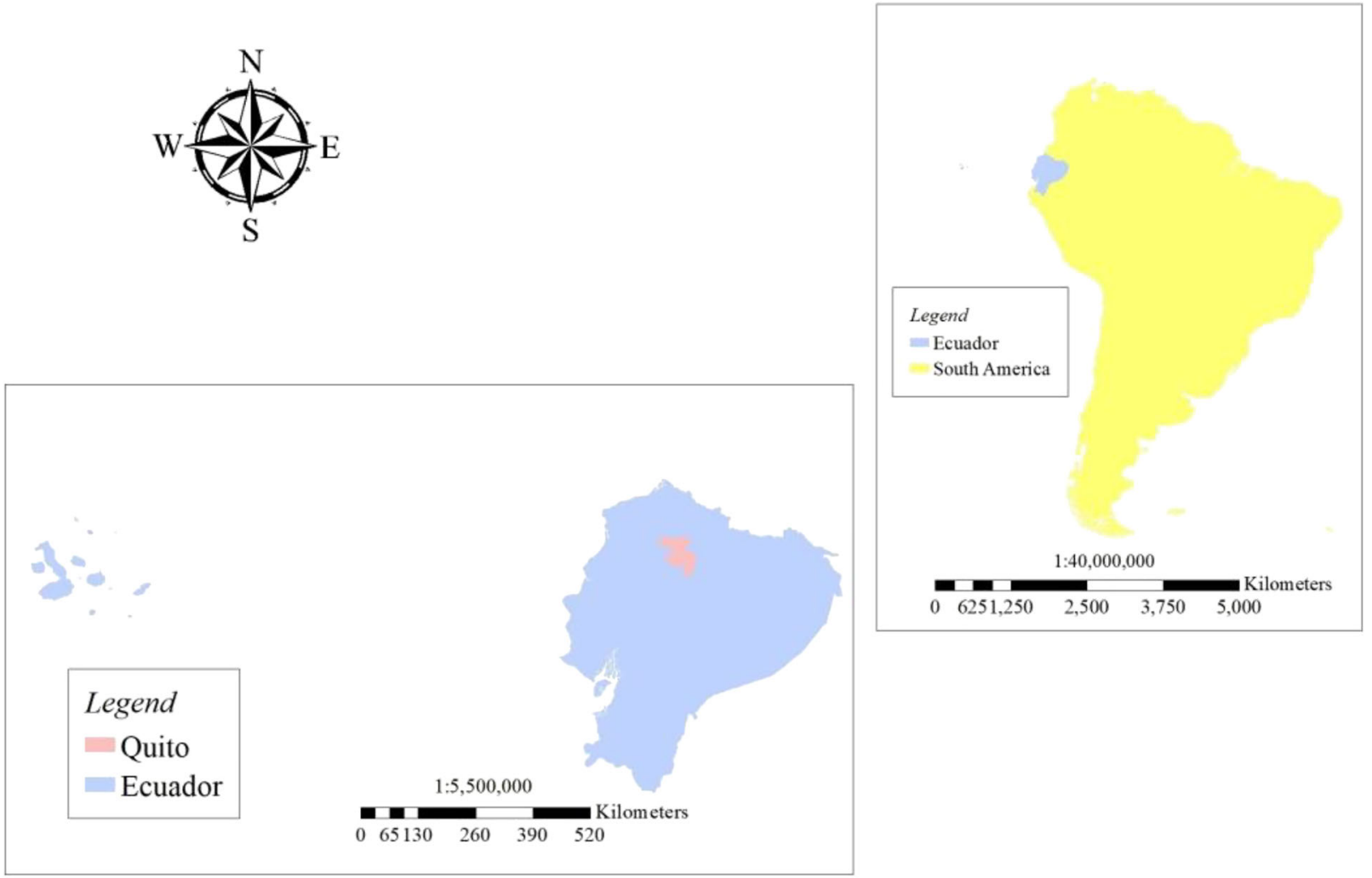

- Kilometers

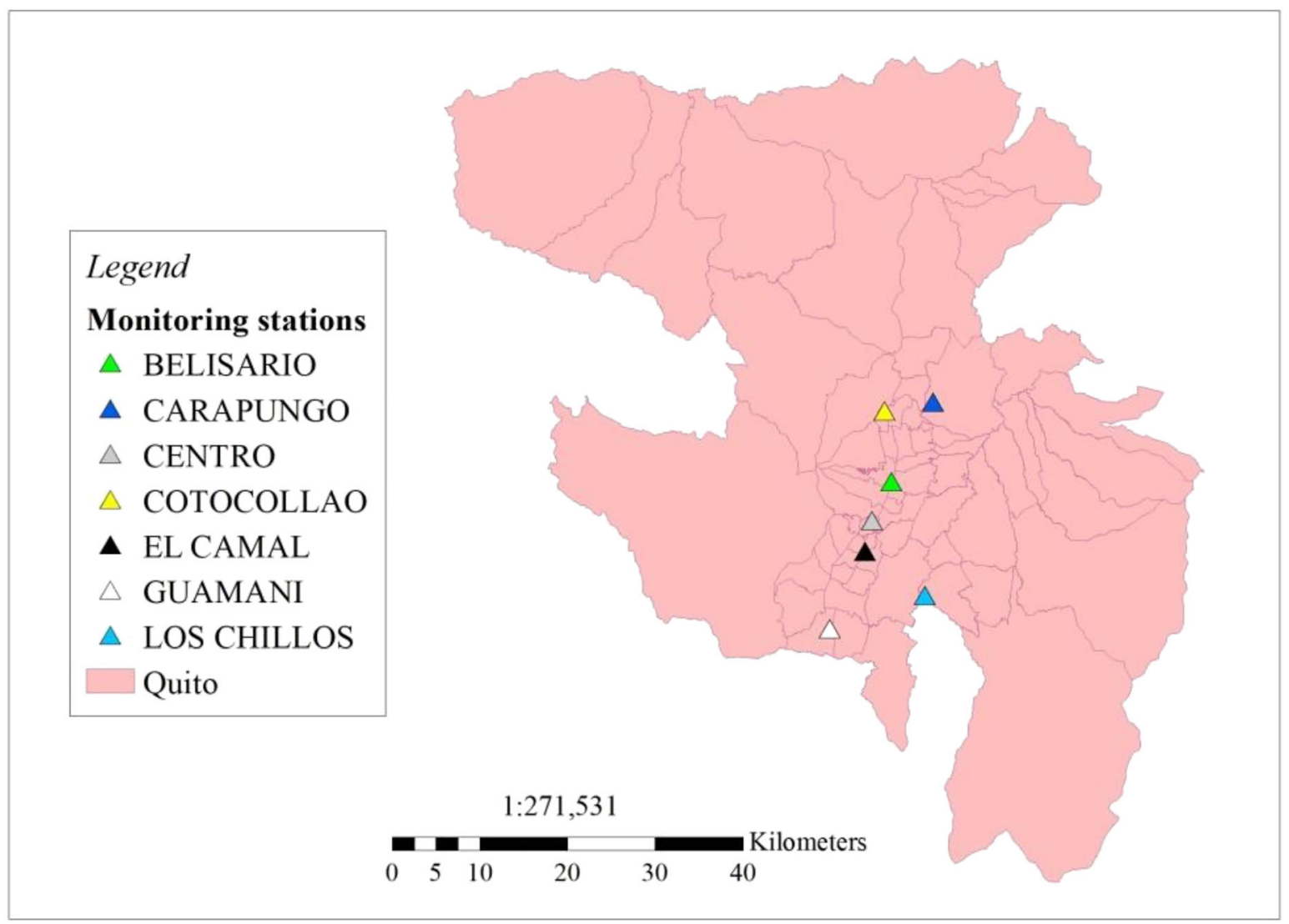

Fig. 1 Location of the study site 
In contrast, $\mathrm{O}_{3}$ concentrations have increased in some European countries (Sicard et al. 2020), Asian countries (Kerimray et al. 2020), and Latin American countries (Nakada and Urban 2020; Siciliano et al. 2020). Ozone is a substance whose molecule is made up of three oxygen atoms. This pollutant could be associated with cardiovascular disease and premature death in people (Turner et al. 2016).

This research aims to determine if the quarantine policies adopted by the government of Ecuador have had a significant impact on air quality in Quito, its capital city. The historical evolution of the concentrations of $\mathrm{NO}_{2}, \mathrm{PM} 2.5$, and $\mathrm{O}_{3}$ in March 2020 was compared against those of March 2018 and March 2019. Using parametric models, it was found that there are significant differences in the concentrations of $\mathrm{NO}_{2}$, $\mathrm{PM} 2.5$, and $\mathrm{O}_{3}$ from 2020 compared with the other years. However, these differences vary according to the monitoring station (there are seven in total). The rest of the document is structured as follows: Section 2 describes the methodology used, Section 3 presents the main results, and Section 4 concludes.

\section{Methodology}

\section{Data}

Data on $\mathrm{NO}_{2}, \mathrm{PM} 2.5$, and $\mathrm{O}_{3}$ concentrations were collected from the Secretary of the Environment of the Municipality of the Metropolitan District of Quito (Secretaria de Ambiente 2020). These variables are measured in micrograms per cubic meter $\left(\mu \mathrm{g} / \mathrm{m}^{3}\right)$. Information was obtained from seven monitoring stations: Belisario, Carapungo, Centro, Cotocollao, El Camal, Guamani, and Los Chillos (Fig. 1). The collection period corresponded to concentrations (measured each hour) from March 25 to March 31, during 2018, 2019, and 2020.

\section{Parametric approach}

This research aims to determine if the $\mathrm{NO}_{2}, \mathrm{PM} 2.5$, and $\mathrm{O}_{3}$ concentrations of the month of March 2020 are statistically different from the concentrations of March 2018 and March 2019. By comparing quantitative variables in two paired samples, parametric and non-parametric approaches can be used to determine if those measurements differ significantly from each other.

The simplest parametric approach to analyze this effect is the test for paired samples. This approach must meet the three requirements: (1) random sample, (2) paired sample, and (3) normal distribution or more than 30 observations $(n>30)$. Compliance with the first condition is explained in detail on the website of the Secretary of the Environment of the Municipality of the Metropolitan District of Quito (http:// www.quitoambiente.gob.ec/ambiente/index.php/ generalidades). On the other hand, at certain hours, measurements were not recorded. To correct this issue, the data from each year were grouped in columns; this was done for each station and pollutant. Then, the missing data for each year was checked, and the incomplete rows were removed. ${ }^{2}$ In this way, paired data was obtained. In all cases, more than 30 concentration observations were achieved.

Following Mehmetoglu and Jakobsen (2017), the $t$ test for paired samples is defined as follows:

$t=\frac{\widehat{X}_{\mathrm{D}}}{\frac{S_{\mathrm{D}}}{\sqrt{n}}}$

where

$\widehat{X}_{\mathrm{D}}$ is the mean of the differences

$S_{\mathrm{D}}$ is the standard deviation of the differences

$n$ is the number of pairs of observations

What the $t$-test is looking for is to test whether the difference is significantly different from zero: If the "independent" variable has no effect, then it should be the same to calculate it before (the quarantine measures) or after (the quarantine measures). The hypotheses raised are

$H_{0}: X_{\mathrm{D}}=0$

$H_{1}: X_{\mathrm{D}} \neq 0$

If the null hypothesis is rejected, there is statistical evidence to affirm that $\mathrm{NO}_{2}, \mathrm{PM} 2.5$, and $\mathrm{O}_{3}$ concentrations from 2020 are statistically different than those from 2018 and 2019.

\section{Results}

Figure 2 shows the evolution of $\mathrm{NO}_{2}$ concentrations every hour (00:00-24:00), from March 25 to 31, 2018, 2019, and 2020. In general, it shows that the 2020 concentrations are lower than in 2018 and 2019. Cotocollao was the station that recorded the lowest concentrations of $\mathrm{NO}_{2}$ in 2020. In contrast, the Belisario station recorded the highest concentrations.

Figure 3 shows the daily (hourly) concentrations of PM2.5. Compared with Fig. 2, the differences in concentrations between years is not as pronounced. In fact, in some stations it is observed that the concentrations of PM2.5 of 2020 exceeded those of 2018 and 2019. However, this occurred only at certain times of the day. On average, PM2.5 concentrations during March 2020 are lower than during March 2018 and March 2019. As in the previous case, the Cotocollao station registered the lowest concentrations of PM2.5 in 2020.

\footnotetext{
$\overline{2}$ The average of data dropped for each pollutant did not exceed $7 \%$ of the total sample.
} 

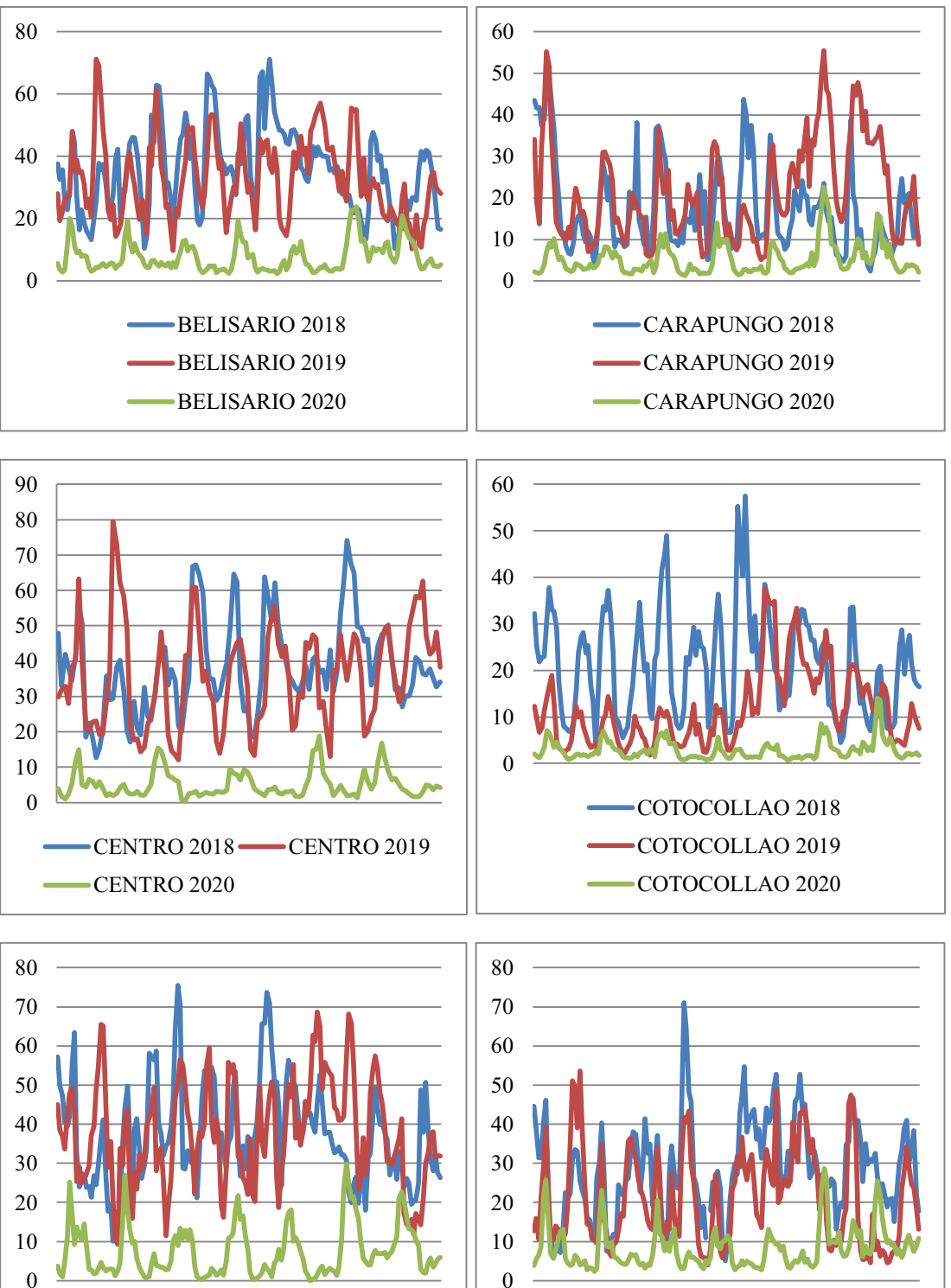

EL CAMAL 2018

EL CAMAL 2019

0

COTOCOLLAO 2018

$\longrightarrow$ COTOCOLLAO 2019

COTOCOLLAO 2020

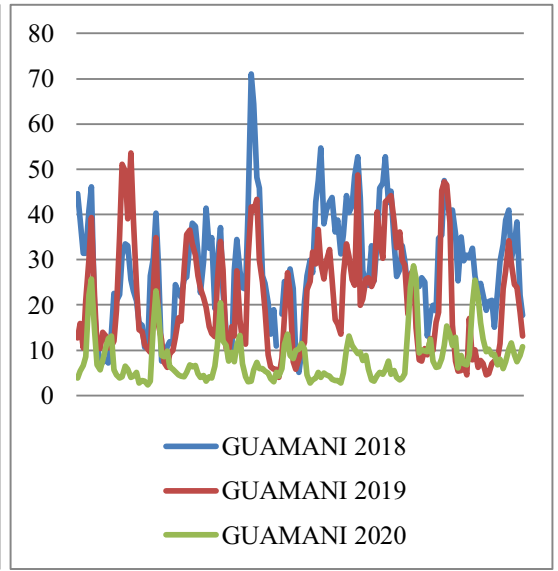

EL CAMAL 2020

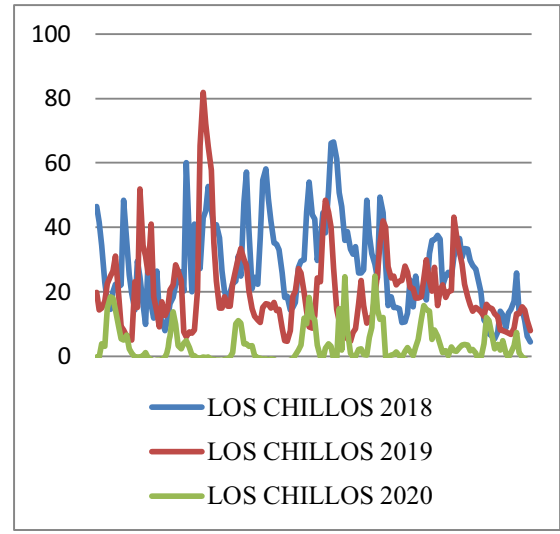

Fig. 2 Evolution of $\mathrm{NO}_{2}\left(\mu \mathrm{g} / \mathrm{m}^{3}\right)$ concentrations 

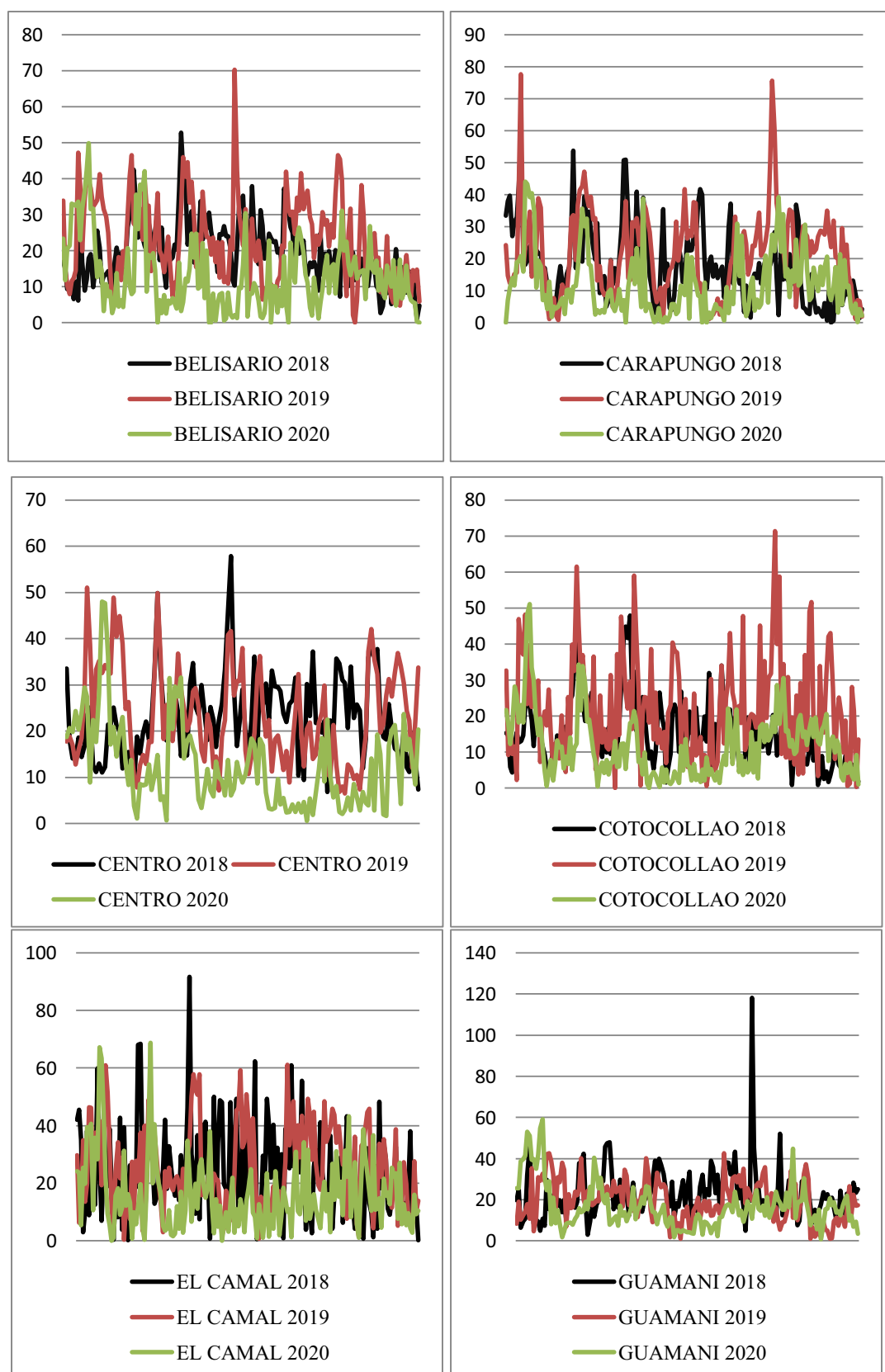

COTOCOLLAO 2018
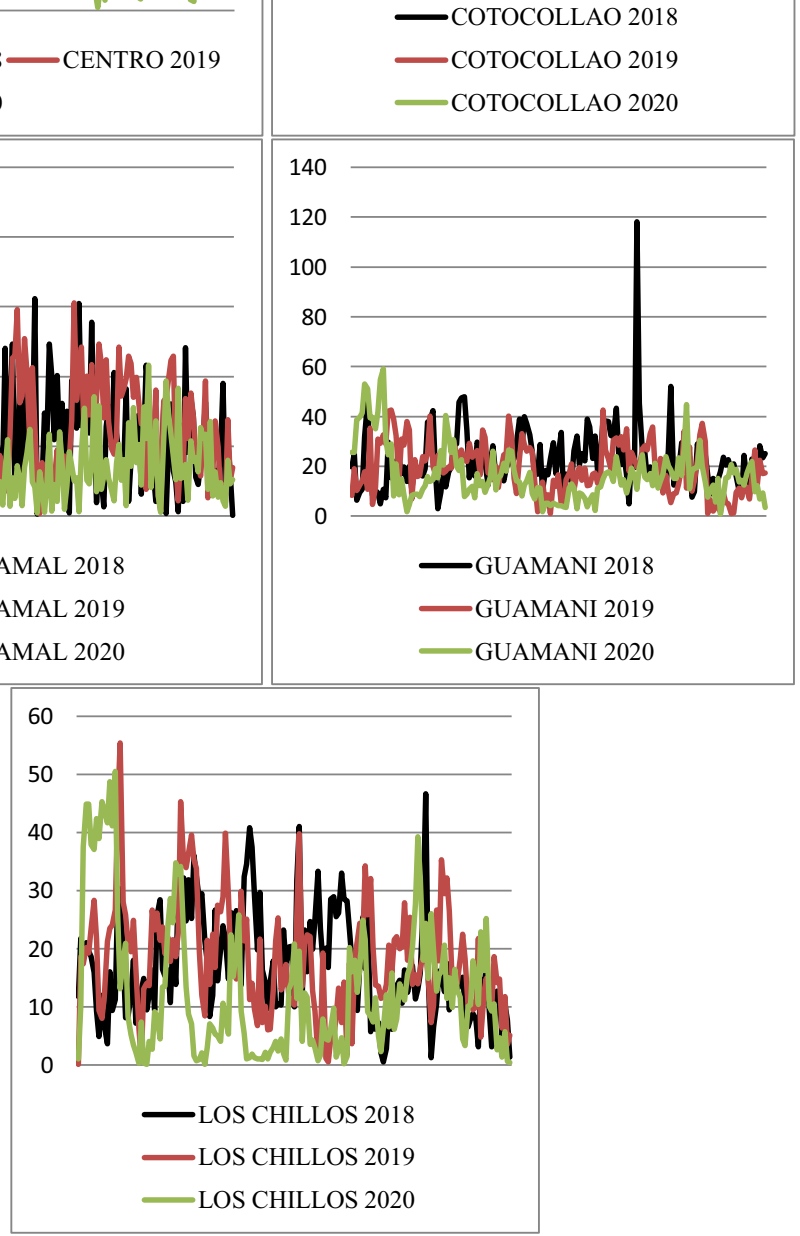

Fig. 3 Evolution of PM2.5 $\left(\mu \mathrm{g} / \mathrm{m}^{3}\right)$ concentrations 
Fig. 4 Evolution of $\mathrm{O}_{3}\left(\mu \mathrm{g} / \mathrm{m}^{3}\right)$ concentrations
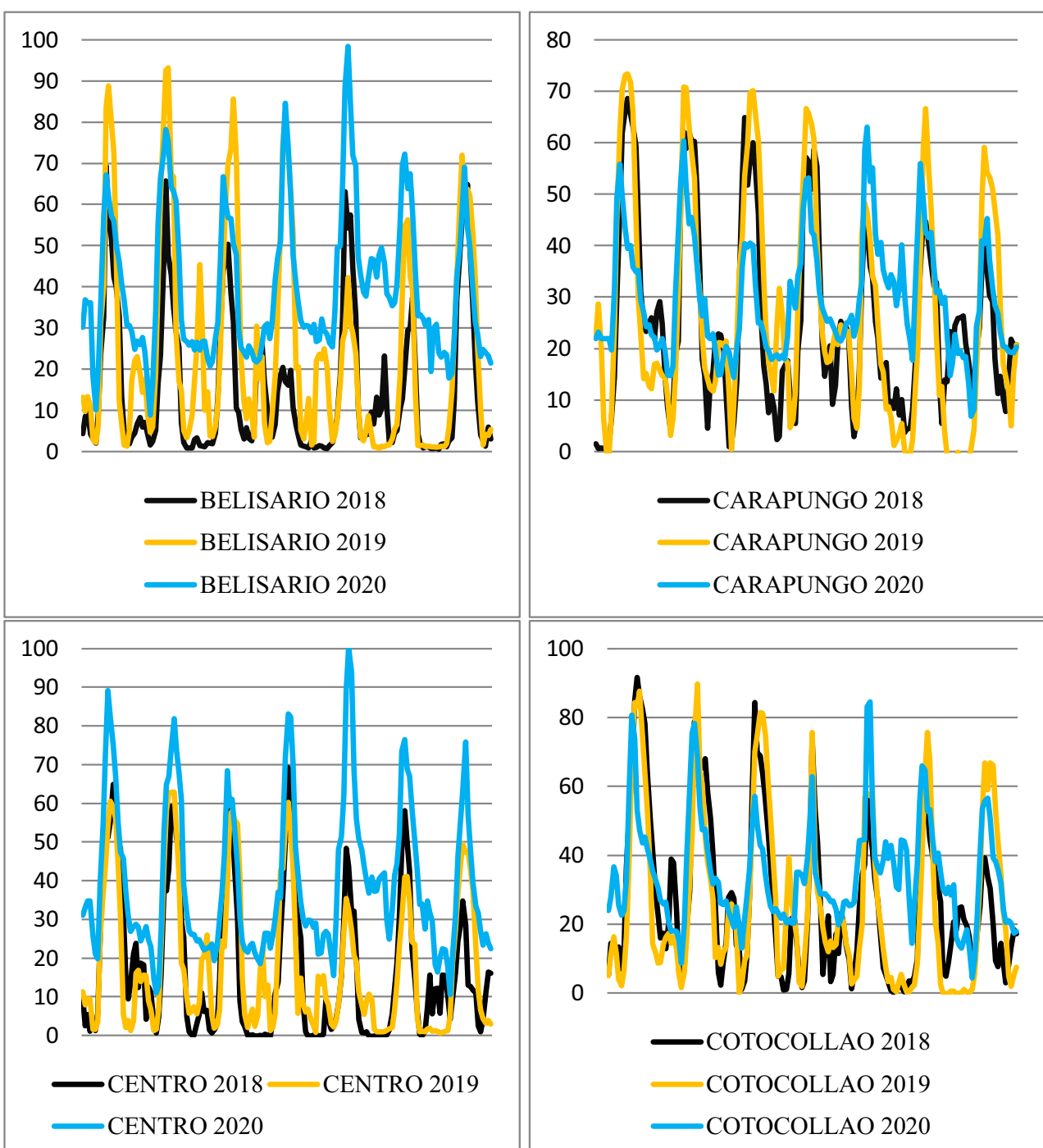

COTOCOLLAO 2019

—COTOCOLLAO 2020

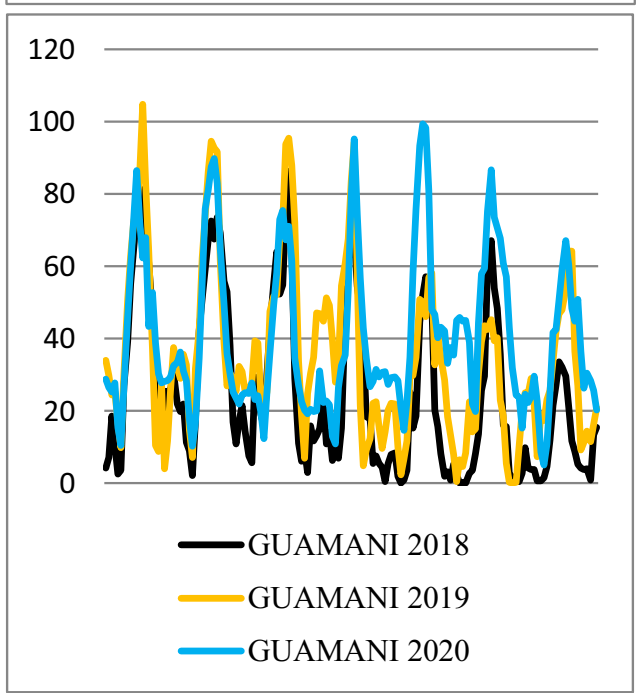

Elaboration: The authors 
Table 1 Results of the parametric test for $\mathrm{NO}_{2}$ concentrations

\begin{tabular}{|c|c|c|c|c|c|c|}
\hline Variables (stations) & $n$ & Mean $\left(\mu \mathrm{g} / \mathrm{m}^{3}\right)$ & Std. Err. & $t$ & $\begin{array}{l}H_{0}: X_{d}=0 \\
\operatorname{Pr}(|T|>|t|)\end{array}$ & Reduction between stations* \\
\hline Belisario 2018 & 160 & 32.86 & 0.99 & 24.36 & 0.000 & 4.27 \\
\hline Belisario 2019 & 160 & 32.90 & 12.73 & 23.11 & 0.000 & 4.27 \\
\hline Belisario 2020 & 160 & 7.70 & 0.38 & & & \\
\hline Carapungo 2018 & 159 & 17.26 & 0.83 & 14.09 & 0.000 & 3.28 \\
\hline Carapungo 2019 & 159 & 21.47 & 0.93 & 20.75 & 0.000 & 4.08 \\
\hline Carapungo 2020 & 159 & 5.26 & 0.30 & & & \\
\hline Centro 2018 & 112 & 38.20 & 1.23 & 26.29 & 0.000 & 7.46 \\
\hline Centro 2019 & 112 & 35.83 & 1.35 & 22.33 & 0.000 & 7.00 \\
\hline Centro 2020 & 112 & 5.12 & 0.36 & & & \\
\hline Cotocollao 2018 & 158 & 21.27 & 0.87 & 21.67 & 0.000 & 7.46 \\
\hline Cotocollao 2019 & 158 & 11.66 & 0.64 & 13.92 & & 4.09 \\
\hline Cotocollao 2020 & 158 & 2.85 & 0.17 & & & \\
\hline El Camal 2018 & 160 & 37.64 & 1.01 & 25.45 & 0.000 & 5.08 \\
\hline El Camal 2019 & 160 & 37.72 & 1.05 & 26.53 & 0.000 & 5.09 \\
\hline El Camal 2020 & 160 & 7.41 & 0.51 & & & \\
\hline Guamani 2018 & 72 & 25.77 & 1.55 & 11.44 & 0.000 & 3.43 \\
\hline Guamani 2019 & 72 & 21.21 & 1.43 & 9.31 & 0.000 & 2.82 \\
\hline Guamani 2020 & 72 & 7.51 & 0.59 & & & \\
\hline Los Chillos 2018 & 160 & 27.99 & 1.08 & 21.55 & 0.000 & 8.16 \\
\hline Los Chillos 2019 & 160 & 20.53 & 1.02 & 15.30 & 0.000 & 5.99 \\
\hline Los Chillos 2020 & 160 & 3.43 & 0.43 & & & \\
\hline Average reduction* & & & & & 2018: 5.59 & 2019: 4.76 \\
\hline
\end{tabular}

*In comparison with 2020 (number of times)

Figure 4 shows the daily concentrations (every hour) of $\mathrm{O}_{3}$. Contrary to the concentrations of PM2.5 and $\mathrm{NO}_{2}$, it is observed that for March 2020, there was a considerable increase in $\mathrm{O}_{3}$ compared with 2018 and 2019. The Guamani station registered the highest concentrations.

Despite certain differences observed in the trends of the pollutants analyzed, it can be affirmed that on average, the concentrations of $\mathrm{NO}_{2}, \mathrm{PM} 2.5$, and $\mathrm{O}_{3}$ show similar trends in each of the years.

On the other hand, Table 1 shows the results of the parametric $t$-test for paired samples. The analysis is performed for each of the monitoring stations. The first thing to note is that the average $\mathrm{NO}_{2}$ concentrations for March 2020 are lower on average than the concentrations for March 2018 and March 2019. This observation had already been noted in Fig. 2. However, it is important to determine if these differences are statistically significant.

To analyze the above, this study tested the statistical significance focusing on the null hypothesis. This hypothesis states that the mean of the differences is equal to zero. By looking at the $p$ value associated with the $t$-test statistic, the null hypothesis is rejected in all cases. In other words, $\mathrm{NO}_{2}$ concentrations from 2020 were significantly lower than those from 2018 and 2019.
Also, Table 1 allows us to analyze which stations registered the biggest and smallest differences in $\mathrm{NO}_{2}$ concentrations in relation to 2020. For example, when comparing 2018 and 2020, the Los Chillos and Carapungo stations recorded the biggest and smallest differences, respectively. When comparing 2019 with 2020, the Los Chillos station recorded the largest difference, while the Guamani station recorded the smallest difference. Overall, $\mathrm{NO}_{2}$ concentrations decreased an average of 5.6 and 4.8 times in March 2020 compared with March 2018 and March 2019, respectively.

The results in Table 2 are interpreted in the same way as in Table 1. The analysis is performed this time for PM2.5 concentrations. The first thing to note is that the difference in means between the years is not as salient as in the case of $\mathrm{NO}_{2}$ concentrations. Again, this had already been noted in Fig. 3. It remains to be determined whether these (apparently small) differences are statistically significant.

The null hypothesis is rejected in all cases, when looking at the $p$ value associated with the $t$-test statistic. That is, PM2.5 concentrations from 2020 are significantly different compared with the concentrations of 2018 and 2019.

However, and like the previous case, these differences vary according to the monitoring station. When comparing 2018 with 2020, the station that registered the greatest variation was 
Table 2 Results of the parametric test for PM2.5 concentrations

\begin{tabular}{|c|c|c|c|c|c|c|}
\hline Variables (stations) & $n$ & Mean $\left(\mu \mathrm{g} / \mathrm{m}^{3}\right)$ & Std. Dev. & $t$ & $\begin{array}{l}H_{0}: X_{d}=0 \\
\operatorname{Pr}(|T|>|t|)\end{array}$ & Reduction between stations* \\
\hline Belisario 2018 & 167 & 19.24 & 0.66 & 5.71 & 0.000 & 1.45 \\
\hline Belisario 2019 & 167 & 22.89 & 0.91 & 9.43 & 0.000 & 1.73 \\
\hline Belisario 2020 & 167 & 13.23 & 0.77 & & & \\
\hline Carapungo 2018 & 164 & 18.29 & 0.91 & 5.70 & 0.000 & 1.53 \\
\hline Carapungo 2019 & 164 & 21.67 & 1.04 & 10.14 & 0.000 & 1.81 \\
\hline Carapungo 2020 & 164 & 11.95 & 0.78 & & & \\
\hline Centro 2018 & 121 & 22.95 & 0.80 & 7.94 & 0.000 & 1.83 \\
\hline Centro 2019 & 121 & 23.23 & 0.94 & 10.83 & 0.000 & 1.85 \\
\hline Centro 2020 & 121 & 12.53 & 0.85 & & & \\
\hline Cotocollao 2018 & 166 & 15.08 & 0.68 & 3.97 & 0.000 & 1.30 \\
\hline Cotocollao 2019 & 166 & 22.41 & 1.09 & 9.87 & 0.000 & 1.93 \\
\hline Cotocollao 2020 & 166 & 11.63 & 0.69 & & & \\
\hline El Camal 2018 & 168 & 23.98 & 1.21 & 5.20 & 0.000 & 1.50 \\
\hline El Camal 2019 & 168 & 25.48 & 1.12 & 7.44 & 0.000 & 1.59 \\
\hline El Camal 2020 & 168 & 15.99 & 0.96 & & & \\
\hline Guamani 2018 & 162 & 22.59 & 0.96 & 4.44 & 0.000 & 1.36 \\
\hline Guamani 2019 & 162 & 19.43 & 0.78 & 2.69 & 0.008 & 1.17 \\
\hline Guamani 2020 & 162 & 16.58 & 0.85 & & & \\
\hline Los Chillos 2018 & 165 & 17.17 & 0.70 & 3.32 & 0.001 & 1.31 \\
\hline Los Chillos 2019 & 165 & 18.25 & 0.74 & 4.83 & 0.000 & 1.40 \\
\hline Los Chillos 2020 & 165 & 13.08 & 0.94 & & & \\
\hline Average reduction* & & & & & 2018: 1.47 & 2019: 1.64 \\
\hline
\end{tabular}

*In comparison to 2020 (number of times)

Carapungo. In contrast, the Cotocollao station was the one that registered the least change between those years. Comparing 2019 with 2020, the station that registered the greatest variation was Cotocollao. In contrast, the Guamani station reported the least variations in PM2.5. The latter is also seen in Fig. 3 (Guamani station), where the variations between years are very small.

Finally, Table 3 presents an analysis of $\mathrm{O}_{3}$ concentrations. Ozone had a significant increase in 2020 since the null hypothesis was rejected in all cases, unlike the PM2.5 and $\mathrm{NO}_{2}$ pollutants. The analysis was carried out on all the monitoring centers, except for the El Camal station, which reported no information for 2020. Compared with 2018 and 2019, ozone levels increased approximately 1.5 and 1.8 times, respectively.

\section{Discussion and conclusion}

During March and April 2020, the government of Ecuador implemented strong lockdown measures to prevent the spread of the new coronavirus. These measures caused a halt of almost all industries. In addition, there were restrictions on private transportation and public transportation completely stopped.
The halt of industries could generate positive and negative effects on the environment. For example, air quality could improve due to the decrease in the use of diesel, a fuel widely used in the transportation industry, and one of the main air pollutants in metropolitan areas (Alahmer 2013). However, the decrease of certain pollutants (such as $\mathrm{NO}_{2}$ and PM2.5) could cause other pollutants (such as $\mathrm{O}_{3}$ ) to increase their concentrations and, therefore, air pollution (Li et al. 2019). Air pollution represents a major environmental health risk (Bherwani et al. 2020; Krishan et al. 2019). The lower the levels of air pollution, the better the cardiovascular and respiratory health of the population, both in the long and short term (WHO 2018).

This research aims to determine if the quarantine policies adopted by the government of Ecuador have had a significant impact on air quality in Quito. In order to determine it, the concentrations of $\mathrm{NO}_{2}, \mathrm{PM} 2.5$, and $\mathrm{O}_{3}$ were studied. The concentrations from March 2020 were compared against those from 2018 and 2019. Using parametric methods, it was found that there are significant differences in the concentrations levels.

For example, it was found that the $\mathrm{NO}_{2}$ concentrations of 2020 were, on average, 5.6 times less than the 2018 concentrations and 4.8 times less than those from 2019. Our results are consistent with the findings of Zhao et al. (2020), Wang 
Table 3 Results of the parametric test for $\mathrm{O}_{3}$ concentrations

\begin{tabular}{|c|c|c|c|c|c|c|}
\hline Variables (stations) & $n$ & Mean $\left(\mathrm{ug} / \mathrm{m}^{3}\right)$ & Std. Dev. & $t$ & $\begin{array}{l}H_{0}: X_{d}=0 \\
\operatorname{Pr}(|T|>|t|)\end{array}$ & Increase between stations* \\
\hline Belisario 2018 & 158 & 15.27 & 1.41 & -25.94 & 0.000 & 2.61 \\
\hline Belisario 2019 & 158 & 24.18 & 1.20 & -10.95 & 0.000 & 1.88 \\
\hline Belisario 2020 & 158 & 39.92 & 1.41 & & & \\
\hline Carapungo 2018 & 159 & 25.08 & 1.43 & -4.50 & 0.000 & 1.19 \\
\hline Carapungo 2019 & 159 & 26.50 & 1.70 & -2.69 & 0.008 & 1.12 \\
\hline Carapungo 2020 & 159 & 29.78 & 0.91 & & & \\
\hline Centro 2018 & 162 & 17.40 & 1.49 & -24.88 & 0.000 & 2.28 \\
\hline Centro 2019 & 162 & 18.57 & 1.45 & -20.86 & 0.000 & 2.13 \\
\hline Centro 2020 & 162 & 39.59 & 1.54 & & & \\
\hline Cotocollao 2018 & 157 & 26.30 & 1.61 & -6.08 & 0.000 & 1.32 \\
\hline Cotocollao 2019 & 157 & 25.83 & 1.98 & -6.18 & 0.000 & 1.34 \\
\hline Cotocollao 2020 & 157 & 34.66 & 1.24 & & & \\
\hline El Camal 2018 & - & - & - & - & - & - \\
\hline El Camal 2019 & - & - & - & - & - & - \\
\hline El Camal 2020** & - & - & - & & & \\
\hline Guamani 2018 & 159 & 25.04 & 1.84 & -13.08 & 0.000 & 1.63 \\
\hline Guamani 2019 & 159 & 35.18 & 1.90 & -3.76 & 0.000 & 1.16 \\
\hline Guamani 2020 & 159 & 40.78 & 1.73 & & & \\
\hline Los Chillos 2018 & 160 & 20.99 & 1.58 & -15.05 & 0.000 & 1.71 \\
\hline Los Chillos 2019 & 160 & 29.59 & 2.27 & -4.39 & 0.000 & 1.21 \\
\hline Los Chillos 2020 & 160 & 35.82 & 1.45 & & & \\
\hline Average increase* & & & & & 2018: 1.48 & 2019: 1.79 \\
\hline
\end{tabular}

*In comparison to 2020 (number of times)

**This station did not report data on $\mathrm{O}_{3}$ concentrations for 2020. Therefore, it was not possible to compare it with the other years

and $\mathrm{Su}$ (2020), Isaifan (2020), Nakada and Urban (2020), Mahato et al. (2020), Kerimray et al. (2020), Berman and Ebisu (2020), and Gautam (2020). They determined significant $\mathrm{NO}_{2}$ reductions for different locations.

It was also found that the PM2.5 concentrations in 2020 were lower (on average) than in 2018 and 2019. Thus, compared with these years, the PM2.5 concentrations were 1.5 and 1.6 times lower, respectively. Previous studies have found similar results in other locations ( $\mathrm{Li}$ et al. 2020; Sharma et al. 2020; Mahato et al. 2020; Kerimray et al. 2020; Berman and Ebisu 2020).

Regarding $\mathrm{O}_{3}$ concentrations, it was found that the ozone levels in 2020 were much higher than the levels in 2018 and 2019. The increase in $\mathrm{O}_{3}$ concentrations could be explained by the decrease in PM2.5 concentrations, which can cause more sunlight to pass through the atmosphere, encouraging more photochemical activities and, therefore, higher $\mathrm{O}_{3}$ production (Dang and Liao 2019; Li et al. 2019). Compared with 2018, ozone concentrations increased approximately 1.5 times. The increase was almost double, comparing 2019 with 2020.

Our research has certain limitations. For example, meteorological and transport processes were not taken into account when carrying out the parametric test. This issue can certainly affect the levels of $\mathrm{NO}_{2}, \mathrm{PM} 2.5$, and $\mathrm{O}_{3}$ (Zhao et al. 2020). Berman and Ebisu (2020) point out that weather can affect pollutant concentrations in the short term, including secondary PM2.5 formation or higher fuel burn emissions due to cold weather. Despite this, the changes in concentrations observed between the years were substantially large to allow us to conclude that these variations are fundamentally attributed to the quarantine policies established during March 2020.

These variations are temporary. Surely, once the lockdown measures are lifted, the concentration levels of these pollutants will return to their average trend. However, as Gautam (2020) points out, there is a very good opportunity for us (scientists/researchers/students/individuals) to learn/ understand how to minimize the concentration level of air pollutants in the long term thanks to the lockdown. In this regard, our results encourage the authorities to establish mechanisms to improve air quality. Furthermore, as Mahato et al. (2020) point out, short-term lockdown (24 days) could be a good alternative. However, to ease the implementation of these types of measures once or twice a year, it is also necessary to analyze the seasonal change in air quality concerning the regional meteorological condition in-depth. 
Future studies could additionally analyze others' contaminants such as carbon monoxide (CO) and particles smaller than $10 \mu \mathrm{m}$ (PM10), among others. In addition, the parametric approach exposed in this work can be replicated to analyze concentrations in other locations, taking into account its limitations.

Acknowledgments The authors are grateful to the editor and the two anonymous reviewers for their valuable comments that substantially improved this manuscript.

\section{Compliance with ethical standards}

Conflict of interest The authors declare that they have no conflict of interest.

\section{References}

Alahmer A (2013) Influence of using emulsified diesel fuel on the performance and pollutants emitted from diesel engine. Energy Convers Manag 73:361-369

Berman JD, Ebisu K (2020) Changes in US air pollution during the COVID-19 pandemic. Sci Total Environ 739:139864

Bherwani H, Nair M, Musugu K, Gautam S, Gupta A, Kapley A, Kumar R (2020) Valuation of air pollution externalities: comparative assessment of economic damage and emission reduction under COVID-19 lockdown. Air Quality, Atmosphere \& Health:1-12

Chen R, Samoli E, Wong CM, Huang W, Wang Z, Chen B et al (2012) Associations between short-term exposure to nitrogen dioxide and mortality in 17 Chinese cities: the China Air Pollution and Health Effects Study (CAPES). Environ Int 45:32-38

Cui Y, Zhang W, Bao H, Wang C, Cai W, Yu J, Streets DG (2019) Spatiotemporal dynamics of nitrogen dioxide pollution and urban development: satellite observations over China, 2005-2016. Resour Conserv Recycl 142:59-68

Dang R, Liao H (2019) Radiative forcing and health impact of aerosols and ozone in China as the consequence of clean air actions over 2012-2017. Geophys Res Lett 46(21):12511-12519

Gautam S (2020) COVID-19: air pollution remains low as people stay at home. Air Quality, Atmosphere, \& Health. https://doi.org/10.1007/ s11869-020-00842-6

Isaifan RJ (2020) The dramatic impact of Coronavirus outbreak on air quality: has it saved as much as it has killed so far? Global Journal of Environmental Science and Management 6(3):275-288

Kerimray A, Baimatova N, Ibragimova OP, Bukenov B, Kenessov B, Plotitsyn P, Karaca F (2020) Assessing air quality changes in large cities during COVID-19 lockdowns: the impacts of traffic-free urban conditions in Almaty, Kazakhstan. Sci Total Environ 730: 139179

Khaniabadi YO, Goudarzi G, Daryanoosh SM, Borgini A, Tittarelli A, De Marco A (2017) Exposure to PM10, NO2, and O3 and impacts on human health. Environ Sci Pollut Res 24:2781-2789

Krishan M, Jha S, Das J, Singh A, Goyal MK, Sekar C (2019) Air quality modelling using long short-term memory (LSTM) over NCT-Delhi, India. Air Quality, Atmosphere \& Health 12(8):899-908

Latza U, Gerdes S, Baur X (2009) Effects of nitrogen dioxide on human health: systematic review of experimental and epidemiological studies conducted between 2002 and 2006. Int J Hyg Environ Health 212:271-287

Li K, Jacob DJ, Liao H, Shen L, Zhang Q, Bates KH (2019) Anthropogenic drivers of 2013-2017 trends in summer surface ozone in China. Proc Natl Acad Sci 116(2):422-427

Li L, Li Q, Huang L, Wang Q, Zhu A, Xu J et al (2020) Air quality changes during the COVID-19 lockdown over the Yangtze River Delta region: an insight into the impact of human activity pattern changes on air pollution variation. Sci Total Environ 732:139282

Mahato S, Pal S, Ghosh KG (2020) Effect of lockdown amid COVID-19 pandemic on air quality of the megacity Delhi, India. Sci Total Environ 730:139086

Mehmetoglu M, Jakobsen TG (2017) Applied statistics using Stata: a guide for the social sciences. Sage

Ministerio de Gobierno (2020) https://www.gob.ec/mdg/tramites/ emision-salvoconducto-circulacion-durante-emergencia-sanitariacovid-19, Accessed date: 18 April 2020

Nakada LYK, Urban RC (2020) COVID-19 pandemic: impacts on the air quality during the partial lockdown in São Paulo state, Brazil. Sci Total Environ 730:139087

Reddington CL, Conibear L, Knote C, Silver BJ, Li YJ, Chan CK, Spracklen DV (2019) Exploring the impacts of anthropogenic emission sectors on PM2.5 and human health in South and East Asia. Atmos Chem Phys 19:11887-11910

Secretaria de Ambiente (2020) http://www.quitoambiente.gob.ec/ ambiente/index.php/datos-horarios-historicos, Accessed date: 17 April 2020

Seinfeld JH, Pandis SN (2016) Atmospheric chemistry and physics: from air pollution to climate change. Wiley, Hoboken

Sharma S, Zhang M, Gao J, Zhang H, Kota SH (2020) Effect of restricted concentrations during COVID-19 on air quality in India. Sci Total Environ 728:138878

Sicard P, De Marco A, Agathokleous E, Feng Z, Xu X, Paoletti E et al (2020) Amplified ozone pollution in cities during the COVID-19 lockdown. Sci Total Environ 735:139542

Siciliano B, Dantas G, Da Silva CM, Arbilla G (2020) Increased ozone levels during the COVID-19 lockdown: analysis for the city of Rio de Janeiro, Brazil. Sci Total Environ 737:139765

Turner MC, Jerrett M, Pope CA III, Krewski D, Gapstur SM, Diver WR, Beckerman BS, Marshall JD, Su J, Crouse DL, Burnett RT (2016) Long-term ozone exposure and mortality in a large prospective study. Am J Respir Crit Care Med 193(10):1134-1142

Wang Q, Su M (2020) A preliminary assessment of the impact of COVID-19 on environment-a case study of China. Sci Total Environ 728:138915

WHO (2018) https://www.who.int/es/news-room/fact-sheets/detail/ambient(outdoor)-air-quality-and-health, Accessed date: 18 April 2020

Xing YF, Xu YH, Shi MH, Lian YX (2016) The impact of PM2. 5 on the human respiratory system. Journal of thoracic disease 8(1):E69-E74

Zambrano-Monserrate MA, Ruano MA, Sanchez-Alcalde L (2020) Indirect effects of COVID-19 on the environment. Sci Total Environ 728:138813

Zhao Y, Zhang K, Xu X, Shen H, Zhu X, Zhang Y, Hu Y, Shen G (2020) Substantial changes in nitrogen dioxide and ozone after excluding meteorological impacts during the COVID-19 outbreak in mainland China. Environ Sci Technol Lett 7(6):402-408

Publisher's note Springer Nature remains neutral with regard to jurisdictional claims in published maps and institutional affiliations. 